\title{
Skłonność do pęknięć gorących austenitycznej stali Super 304H przeznaczonej do pracy w podwyższonej temperaturze
}

\author{
Hot crack sensitivity of Super $304 \mathrm{H}$ austenitic steel \\ for work at increased temperature
}

\section{Streszczenie}

W pracy przedstawiono wyniki badań skłonności do pęknięć gorących austenitycznej stali Super 304H przeznaczonej do pracy w wysokiej temperaturze. Stal została poddana próbie Transvarestraint, a wyniki tej próby zostały porównane z wynikami próby Transvarestraint dla stali 304. Ustalono, że stal Super $304 \mathrm{H}$ wykazuje bardzo dużą skłonność do pęknięć zarówno krystalizacyjnych, jak i segregacyjnych. Ponadto w wysokotemperaturowej strefie wpływu ciepła stwierdzono uszkodzenia granic ziaren o charakterze pęknięć gorących.

\section{Wstęp}

Zapotrzebowanie na energię elektryczną na świecie ciągle wzrasta i jest bezpośrednio związane z rozwojem gospodarczym państw, produkcją przemysłowa, energochłonnościa oraz zarządzeniem energią. Prognozy zużycia energii elektrycznej do $2020 \mathrm{r}$. przedstawiono na rysunku 1 . Aby zagwarantować bezpieczeństwo energetyczne kraju, w którym elektrownie oparte są na spalaniu surowców kopalnych, niezbędne jest ciagłe udoskonalanie oraz zwiększanie sprawności urządzeń energetycznych. Zadanie to może być zrealizowane przez stosowanie coraz nowocześniejszych stali i stopów, które umożliwią podniesienie parametrów pracy kotłów i zapewnią bezpieczną oraz bezawaryjną pracę przez długi czas [1].

Do wysokotemperaturowych części kotłów w zakresie temperatury pracy powyżej $600^{\circ} \mathrm{C}$ stosuje się stale

Inż. Paweł Zbroja, dr inż. Aneta Ziewiec, prof. dr hab. inż. Edmund Tasak - Akademia GórniczoHutnicza, Kraków. austenityczne i stopy niklu. Niestety konwencjonalna stal 304 (wg PN-EN 10088-1, X5CrNi 18-10) nie spełnia tych wymagań ze względu na zbyt niską odporność na pełzanie. Jedną z najnowocześniejszych stali stosowanych obecnie w przemyśle energetycznym, przeznaczoną do pracy w wysokiej temperaturze jest

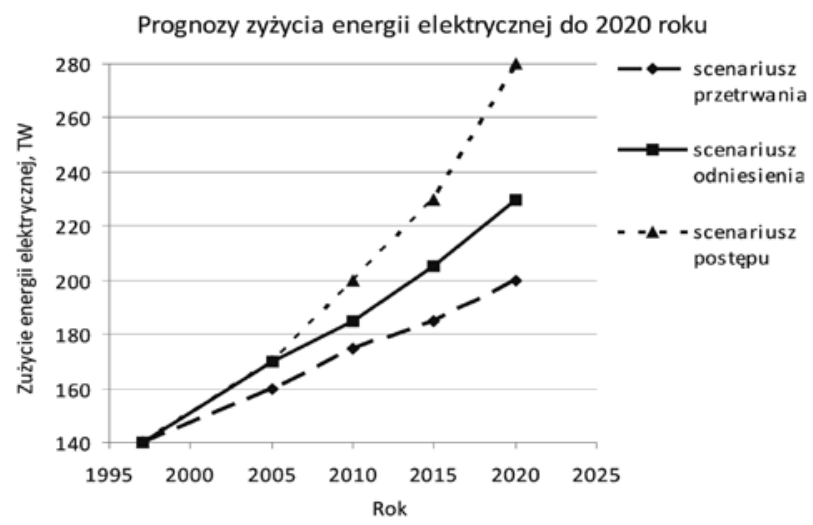

Rys. 1. Prognozy zużycia energii elektrycznej do 2020 r. [1] Fig. 1. Forecasts of electricity consumption by 2020 [1] 


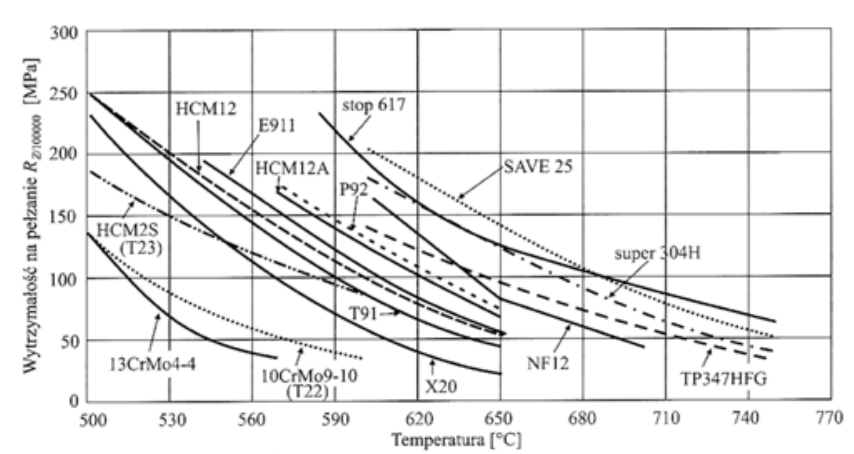

Rys. 2. Wytrzymałość na pełzanie stali ferrytycznych, austenitycznych oraz stopów niklu [2]

Fig. 2. Creep strength of ferritic steels, austenitic steels and nickel alloys [2]

stal Super $304 \mathrm{H}$ (X10CrNiCuNb 18-9-3, nr 1.4907). Przez dodanie do składu chemicznego stali $3 \%$ miedzi, zwiększenie zawartości węgla oraz dodatku niobu i azotu, podniosła się odporność na pełzanie, a co za tym idzie, możliwość pracy w wysokiej temperaturze. Dodatek miedzi i niobu powoduje znaczne zwiększenie odporności na naprężenia rozciągające $w$ wyniku utwardzenia wydzieleniowego związkami niobu i fazą $\varepsilon$ zawierającą $92 \%$ miedzi. Duża zawartość chromu oraz utwardzenie wydzieleniowe powodują, że stal ta charakteryzuje się bardzo dobrą odpornością na korozję wysokotemperaturową oraz bardzo dobrą odpornością na pełzanie, szczególnie w zakresie temperatury $580 \div 640^{\circ} \mathrm{C}$. Na rysunku 2 przedstawiono wytrzymałość na pełzanie po $100000 \mathrm{~h}$ stali ferrytycznych, austenitycznych oraz stopów niklu. Odporność na wysoką temperaturę jest jednym z najważniejszych wymagań, jakie stawia się wobec rur kotłowych.

Podstawowym problemem spawalności stali austenitycznych jest ich skłonność do pęknięć gorących. Stal Super $304 \mathrm{H}$ jest stalą czysto austenityczną, zatem podjęto próbę określenia skłonności do pęknięć gorących tego materiału. Technologiczną próbą, która pozwala określić wpływ odkształceń na skłonność do pęknięć gorących materiału spawanego i materiałów dodatkowych, jest próba Varestraint i Transvarestraint. Charakteryzuje się ona dużą prostotą wykonania oraz ekonomicznością. Pozwala określić wpływ zarówno poszczególnych procesów, jak i parametrów spawania, na tworzenie się pęknięć gorących. Badania wykonywane są na próbkach o wymiarach $220 \times 50 \times g ~ m m$ (gdzie: $\mathrm{g}$ - grubość materiału), które przetapia się bez materiału dodatkowego lub wykonuje napoinę. Schemat urządzenia oraz zasadę działania przedstawiono na rysunku 3. Podczas dojścia łuku do punktu A sterowane pneumatycznie jarzmo zgina próbkę $w$ dół, odtwarzając krzywiznę górnej powierzchni wymiennego bloku matrycowego $\mathrm{B}$.

Do obliczenia wielkości odkształcenia skrajnych włókien próbki wykorzystuje się zależność:

$$
\varepsilon=g / 2 R
$$

gdzie: g - grubość próbki, mm; R - promień krzywizny górnej płaszczyzny bloku matrycowego, $\mathrm{mm}$. a) $\stackrel{\text { kierunek spawania }}{\longrightarrow}$

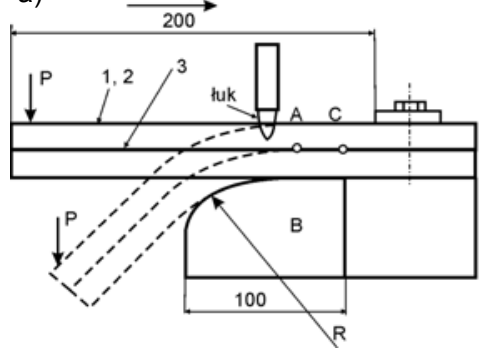

b)

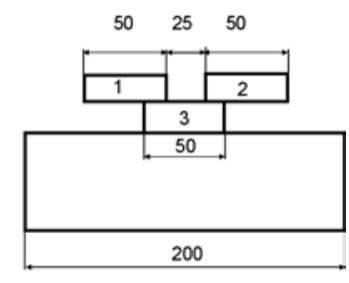

Rys. 3. Schemat próby Varestraint: a) widok wzdłużny, b) widok poprzeczny [3]

Fig. 3. Schematic diagram of Varestraint test: a) longitudinal view, b) transverse view [3]

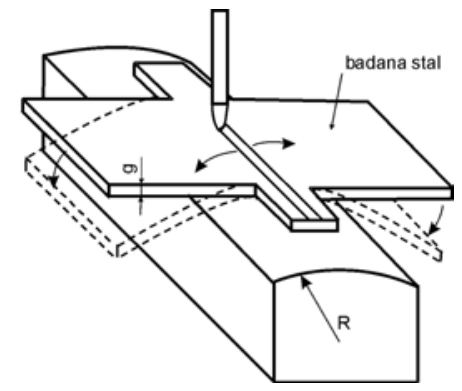

Zmieniając bloki matrycowe o różnych promieniach, możemy zmieniać wielkość odkształcenia. Podczas wykonywania próby pod wpływem wywołanych odkształceń pojawiają się pęknięcia w napoinie lub obszarze przyspoinowym materiału rodzimego.

W celu uzyskania oceny technologicznej wytrzymałości materiału należy określić:

- minimalne odkształcenie konieczne do wywołania pęknięcia, tzw. próg pękania,

- sumaryczną długość wszystkich pęknięć,

- maksymalną długość pęknięcia.

Pierwsze dwa kryteria charakteryzują odporność metalu na powstawanie pęknięć gorących, trzecie natomiast określa zakres kruchości wysokotemperaturowej. Wadą tej metody jest to, że odkształceniu ulega nie tylko metal napoiny, ale również materiał rodzimy, co pogarsza dokładność wyników.

Próbę Varestraint charakteryzuje to, że pęknięcia gorące usytuowane są prostopadle do kierunku spawania. W praktyce natomiast częściej spotyka się pęknięcia gorące usytuowane równolegle do kierunku spawania. Dlatego próba ta została zmodyfikowana tak, aby naprężenia rozciągające były prostopadłe do osi spoiny (próba Transvarestraint). Schemat przebiegu próby przedstawiono na rysunku 4 . Kryteria oceny są takie same jak w próbie Varestraint.

\section{Materiały i przebieg badań}

Do badań wykorzystano dwie stale: Super $304 \mathrm{H}$ oraz 304, których skład chemiczny przedstawiono w tablicy I.

$Z$ tych materiałów wykonano 2 serie badań (seria A) na próbkach ze stali Super $304 \mathrm{H}$ oraz serię badań 
Tablica I. Skład chemiczny (analiza wytopowa) w \% masowych stali Super 304H

Table I. Chemical composition (casts study) in \% by mass of Super $304 \mathrm{H}$ steel

\begin{tabular}{|c|c|c|c|c|c|c|c|c|c|c|c|c|}
\hline \multirow{2}{*}{ Stal } & \multicolumn{12}{|c|}{ Zawartość pierwiastków, \% masowe } \\
\hline & C & Si max & Mn max & $P$ max & $S \max$ & $\mathrm{Cr}$ & $\mathrm{Ni}$ & $\mathrm{Nb}$ & $\mathrm{Cu}$ & $\mathrm{N}$ & Al. & B \\
\hline $304 \mathrm{H}$ & 0,07 & 0,30 & 1,00 & 0,04 & 0,01 & $17,0-19,0$ & $7,5-10,5$ & $0,30-0,60$ & $2,50-3,50$ & $0,05-0,12$ & $0,003-0,03$ & $0,001-0,01$ \\
\hline 304 & 0,03 & 1,00 & 2,00 & 0,045 & 0,015 & $17,0-19,0$ & $9,0-11,0$ & - & - & 0,011 max & - & - \\
\hline
\end{tabular}

na próbkach ze stali 304 (seria C), które posłużyły do przeprowadzenia próby Transvarestraint.

Podczas próby Transvarestraint kolejne próbki odkształcano na blokach matrycowych o odpowiednim promieniu krzywizny górnej płaszczyzny $(R=135,38$, 30 i $17 \mathrm{~mm}$ ). Ponadto zostało wykonane samo przetopienie bez odkształcania. Wymiary próbek wynosiły 220x50x4 mm. Powierzchnie próbek (blach) były szlifowane papierami ściernymi w celu usunięcia wierzchniej warstwy tlenków oraz zanieczyszczeń. Przygotowane w ten sposób próbki zostały wykorzystane do badań. Parametry przetapiania podłoża metodą TIG zostały przedstawione w tablicy II.

Badania wykonano na skonstruowanym w Katedrze Metaloznawstwa i Metalurgii Proszków uniwersalnym stanowisku, na którym można przeprowadzać zarówno próbę Varestraint, jak i Transvarestraint (rys. 5).

Tablica II. Parametry przetapiania

Table II. Parameters of melting

\begin{tabular}{|l|c|}
\hline \multicolumn{2}{|c|}{ Parametr } \\
\hline Natężenie prądu & $80 \mathrm{~A}$ \\
\hline Rodzaj prądu & $\mathrm{DC}$ \\
\hline Średnica elektrody wolframowej & $2 \mathrm{~mm}$ \\
\hline Rodzaj gazu ochronnego & argon \\
\hline Natężenie gazu ochronnego & $10 \mathrm{l} / \mathrm{min}$ \\
\hline
\end{tabular}

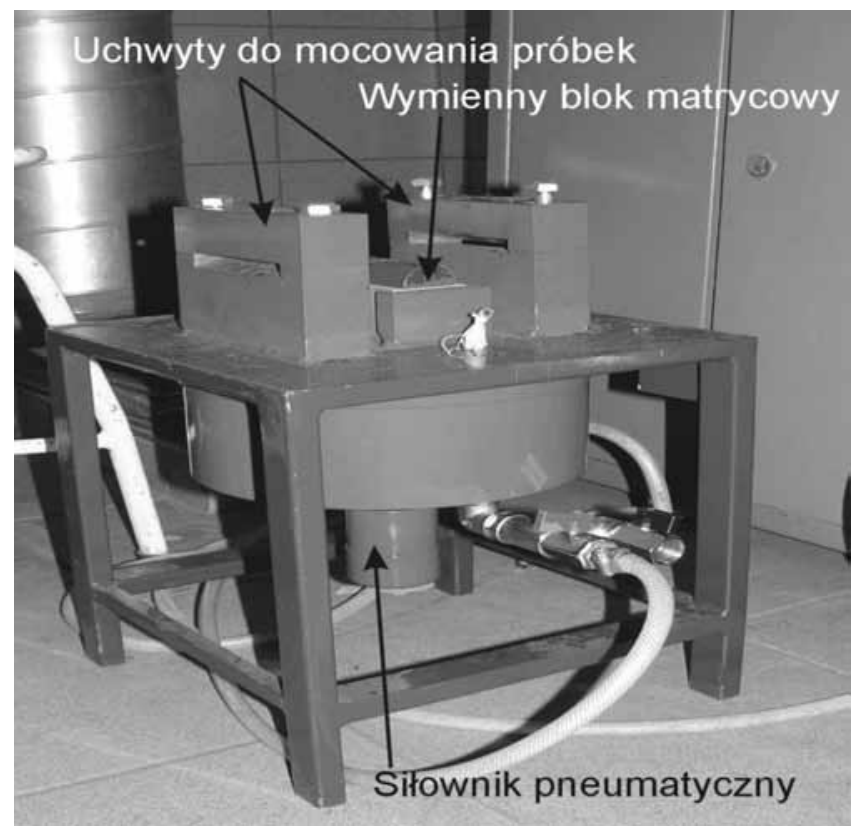

Rys. 5. Stanowisko do próby Transvarestraint

Fig. 5. The position to carry out Transvarestraint test

\section{Wyniki badań}

W tablicy III zestawiono wyniki pomiarów sumarycznej i maksymalnej długości pęknięć, natomiast na rysunkach 6 i 7 przedstawiono zależność sumarycznej długości pęknięć oraz maksymalnej długości pęknięcia od wielkości przyłożonego odkształcenia. $Z$ danych przedstawionych w tablicy III i na rysunkach 6 i 7 widać, że nawet odkształcenie poniżej $2 \%$ powoduje powstanie pęknięć gorących w spoinie stali Super $304 \mathrm{H}$, natomiast w stali 304 nawet ponad $11 \%$ odkształcenie nie wywołuje pękania gorącego. Jest to potwierdzeniem faktu, że stale czysto austenityczne (stal Super 304H), w których występuje krzepnięcie austenityczne, są bardzo skłonne do pęknięć gorących krystalizacyjnych, natomiast stale, w których występuje krzepnięcie ferrytyczne (stal 304), nie są skłonne do pęknięć [4].

Po wykonaniu prób zostały przeprowadzone badania wizualne pęknięć, badania mikroskopowe

Tablica III. Wyniki próby Transvarestraint Table III. Results of Transvarestraint tests

\begin{tabular}{|c|c|c|c|c|c|}
\hline $\begin{array}{l}\bar{y} \\
\frac{\overline{0}}{0} \\
\overline{0} \\
\bar{L}\end{array}$ & 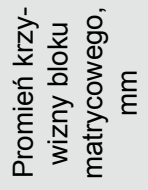 & 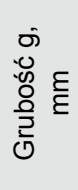 & 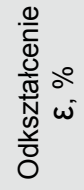 & 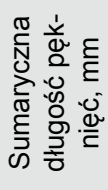 & 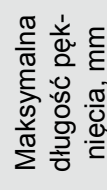 \\
\hline $1 \mathrm{~A}$ & 135 & 5 & 1,85 & 3,32 & 0,95 \\
\hline $2 \mathrm{~A}$ & 38 & 5 & 6,7 & 4,84 & 1,02 \\
\hline $3 A$ & 30 & 5 & 8,33 & 5,25 & 1,22 \\
\hline $4 \mathrm{~A}$ & 17 & 5 & 14,71 & 5,42 & 1,46 \\
\hline $1 \mathrm{C}$ & 135 & 4 & 1,48 & brak & brak \\
\hline $2 \mathrm{C}$ & 30 & 4 & 6,67 & brak & brak \\
\hline $3 C$ & 17 & 4 & 11,76 & brak & brak \\
\hline
\end{tabular}

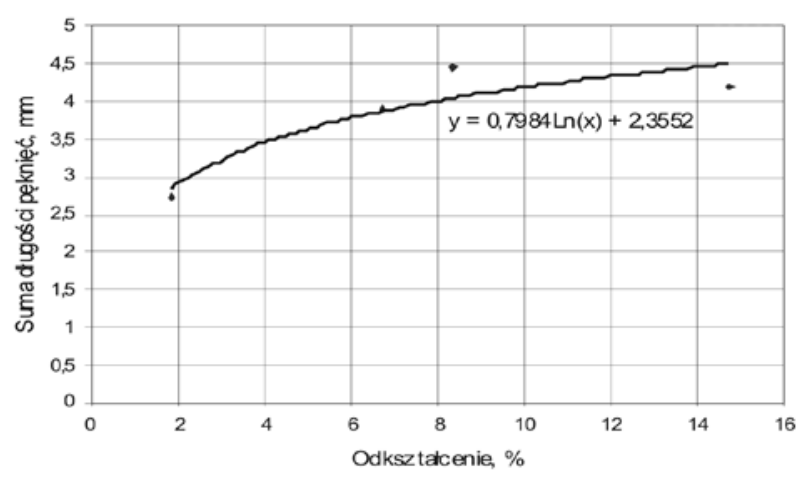

Rys. 6. Zależność sumarycznej długości pęknięć od odkształcenia próbek

Fig. 6. Dependence of the total length of cracks from the strain of samples 


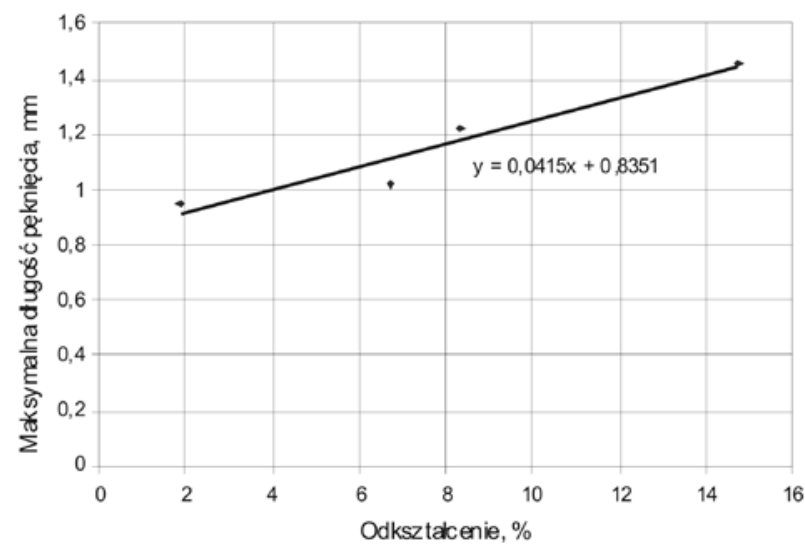

Rys. 7. Zależność maksymalnej długości pęknięć od odkształcenia próbek

Fig. 7. The dependence of the maximum length of the cracks from the strain of samples

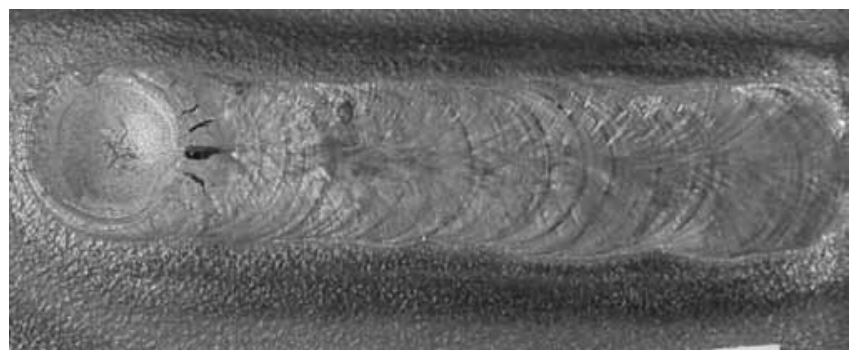

Rys. 8. Powierzchnia próbki stali Super $304 \mathrm{H}$ z widocznymi pęknięciami krystalizacyjnymi (odkształcenie 14,7\%)

Fig. 8. Super $304 \mathrm{H}$ steel sample surface with visible crystalline cracks (strain $14.7 \%$ )

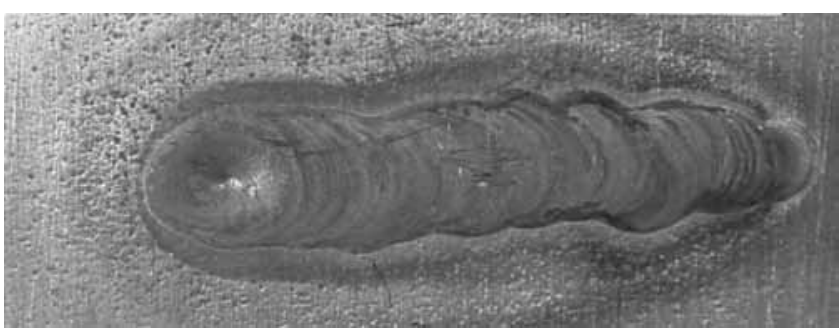

Rys. 9. Powierzchnia próbki stali 304 bez pęknięć (odkształcenie $11,7 \%)$

Fig. 9. 304 steel sample surface without cracks (strain 11.7\%)

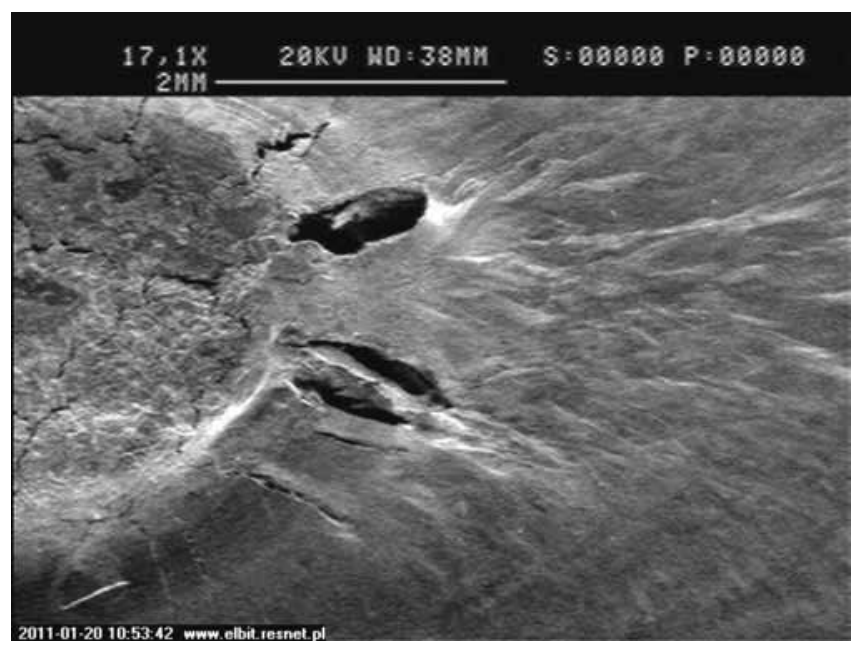

Rys. 10. Pęknięcia gorące spoiny w pobliżu krateru

Fig. 10. Hot cracks of weld near to the crater powierzchni i przekroi poprzecznych oraz badania powierzchni w elektronowym mikroskopie skaningowym. Przykłady wyglądu powierzchni spoiny stali 304H i 304 pokazano na rysunkach 8 i 9.

Pęknięcia gorące krystalizacyjne powstają w obszarze dwufazowym ciecz + austenit, a duża długość pęknięcia maksymalnego wynosząca $1,5 \mathrm{~mm}$ wskazuje na szeroki zakres temperatury krzepnięcia stali $304 \mathrm{H}$. Pęknięcia gorące na powierzchni spoiny, obserwowane w mikroskopie skaningowym, pokazano na rysunku 10. Rysunek 11 przedstawia powierzchnę w strefie wpływu ciepła z widocznymi powierzchniowymi pęknięciami po granicach ziaren. Aby stwierdzić, czy są to pęknięcia cienkiej warstwy tlenków, czy pęknięcia w materiale, wykonano zgłady równolegle oraz prostopadle do powierzchni próbki. Przykłady pokazane na rysunkach 12 i 13 wskazują, że są to drobne pęknięcia lub uszkodzenia granic ziaren wypełnione tlenkami na głębokość porównywalną z wielkością ziarna stali $(15 \div 20 \mathrm{~mm})$. Mechanizm powstawania tych pęknięć będzie wyjaśniony podczas dalszych badań.

Oprócz pęknięć krystalizacyjnych w spoinie i pęknięć powierzchniowych w SWC, w badanej stali stwierdzono pęknięcia segregacyjne w SWC, które w obecności naprężeń rozciągających przechodzą do spoiny.

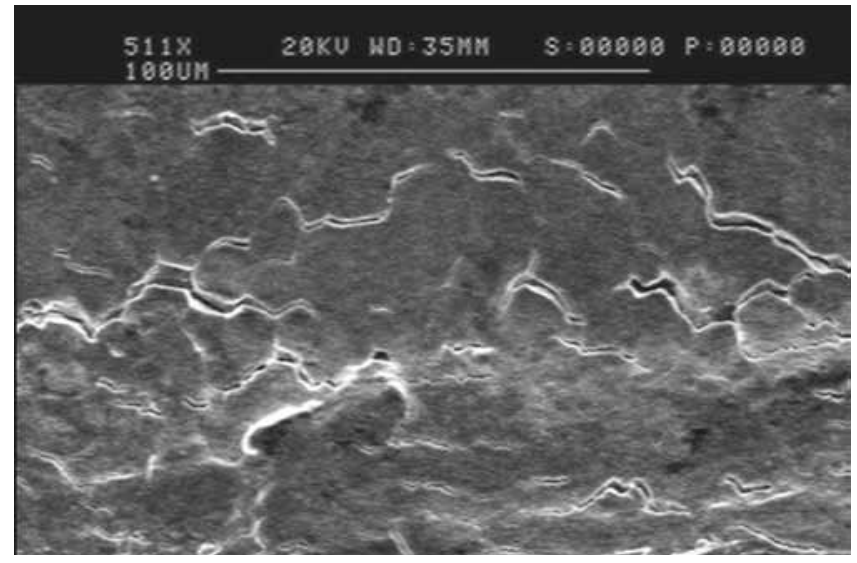

Rys. 11. Pęknięcia gorące po granicach ziaren w SWC Fig. 11. Hot cracks in the grain boundaries in the HAZ

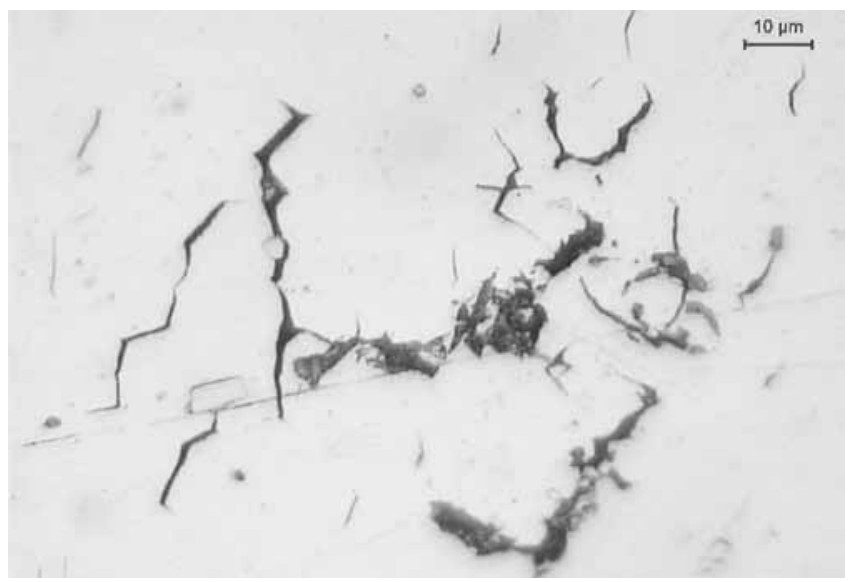

Rys. 12. Uszkodzenia granic ziaren, widoczne na zgładzie wykonanym równolegle do powierzchni blachy (zgład nietrawiony)

Fig. 12. Damage of grain boundaries visible on the metallographic specimen parallel to the surface of the plate (not etched) 


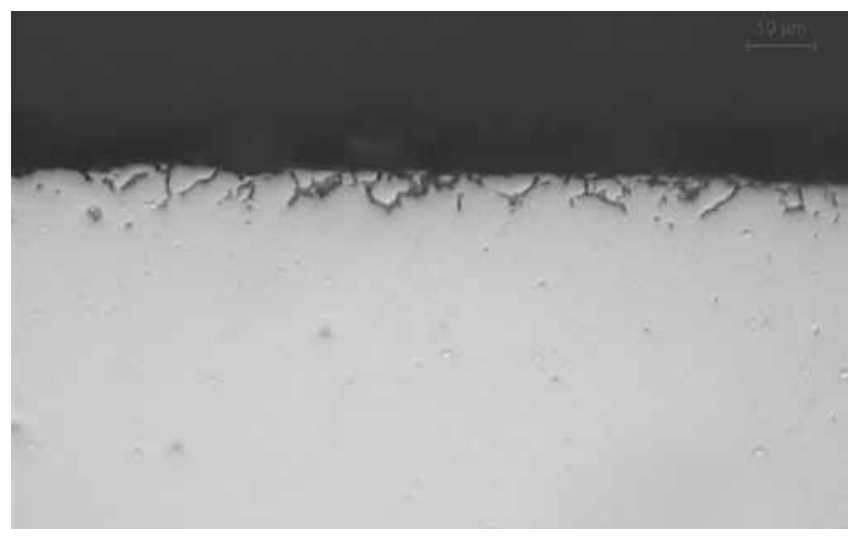

Rys. 13. Uszkodzenia granic ziaren w SWC widoczne na zgładzie prostopadłym do powierzchni blachy (zgład nietrawiony)

Fig. 13. Damage of grain boundaries in the SWC visible on the metallographic specimen perpendicular to the sheet surface (not etched)

Przykłady tych pęknięć pokazano na rysunku 14. Pęknięcia segregacyjne powstają przy węglikach niobu, na których zatrzymała się migrująca granica ziaren. W pobliżu węglika niobu zachodzi nadtapianie sąsiadującego z nim austenitu i powstaje ciecz bogata w niob o niskiej temperaturze krzepnięcia [4]. Naprężenia powodują
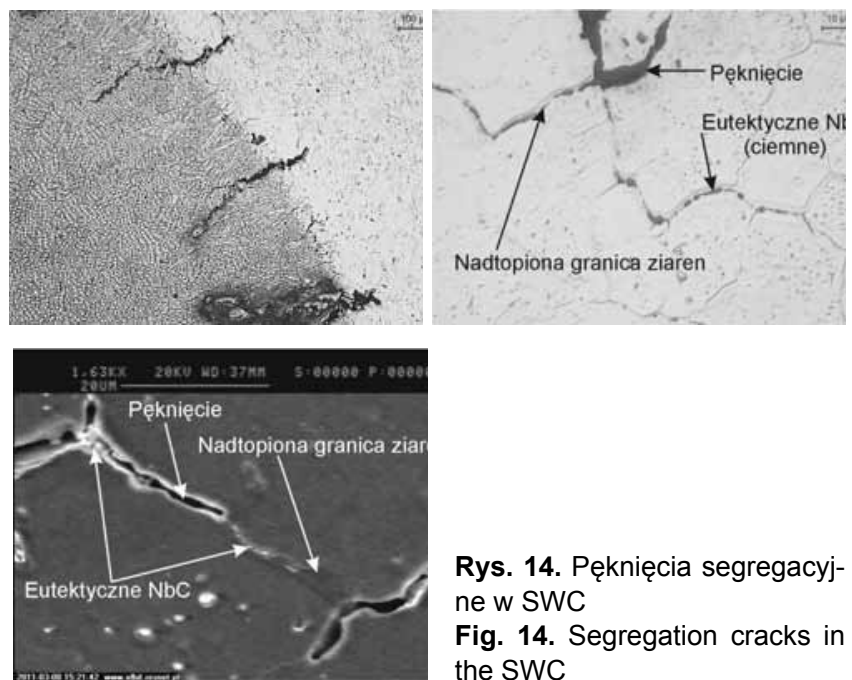

Rys. 14. Pęknięcia segregacyjne w SWC

Fig. 14. Segregation cracks in the SWC

rozpływanie się cieczy po granicach ziaren. Zmniejszenie objętości cieczy przy krzepnięciu i powstające odkształcenia wywołane skurczem powodują powstawanie pęknięć gorących, tzw. segregacyjnych. Wewnątrz pęknięć gorących resztka cieczy bogatej w niob krzepnie w postaci eutektyki.

\section{Podsumowanie}

Badania wykazały, że stal austenityczna Super $304 \mathrm{H}$ jest skłonna do pęknięć krystalizacyjnych w spoinie oraz pęknięć segregacyjnych w SWC. Duża skłonność do pęknięć krystalizacyjnych jest wynikiem składu stali, w której występuje krzepnięcie austenityczne. Ponadto obecność silnie segregującego na granicach ziaren niobu znacząco obniża temperaturę końca krzepnięcia, co przy znacznych odkształceniach skurczowych sprzyja pękaniu.

Drugim rodzajem pęknięć są pęknięcia segregacyjne powstające w strefie wpływu ciepła i rozwijające się w kierunku spoiny. Ich przyczyną jest nadtapianie austenitu wokół węglików niobu i przy ponownym krzepnięciu tworzenie niskotopliwych eutektyk austenit $+\mathrm{NbC}$. Zmniejszenie objętości cieczy przy krzepnięciu i powstające odkształcenia wywołane skurczem powoduja powstawanie gorących pęknięć segregacyjnych. Wewnątrz pęknięć gorących resztka cieczy bogatej w niob krzepnie w postaci eutektyki.

Trzecim rodzajem pęknięć w strefie wpływu ciepła są powierzchniowe uszkodzenia (pęknięcia) wzdłuż granic ziaren do głębokości porównywalnej $z$ wielkością ziarna $(15 \div 20 \mathrm{~mm})$. Mechanizm ich powstawania będzie wyjaśniony w czasie dalszych badań.

Przeprowadzone badania wskazują, że stal Super $304 \mathrm{H}$ może stwarzać problemy w procesie wytwarzania konstrukcji i należy mieć świadomość możliwości wystąpienia niezgodności spawalniczych, niekiedy trudnych do ujawnienia.

\section{Literatura}

[1] Hernas A.: Trwałość i niszczenie elementów kotłów i turbin parowych, Wydawnictwo Politechniki Ślaskiej, Gliwice 2003.

[2] Brózda J., Zeman M., Pasternak J.: The first supercritical power unit in Poland. Weldability evaluation of new martensitic chromium steels with tungsten additions and properties of wel- ded joins. Proceedings of the 7th Liege Conference, 2000, 1711-1720 (część III).

[3] Tasak E., Ziewiec A.: Spawalność materiałów konstrukcyjnych, t.1, Spawalność stali, Wydawnictwo JAK, Kraków 2009.

[4] Tasak E.: Metalurgia spawania, Wydawnictwo JAK, Kraków 2008.

Wyniki prezentowanych badań zostały przedstawione w referacie pt. „Spawalność stali austenitycznych, przeznaczonych do pracy w podwyższonych temperaturach" wygłoszonym przez inż. Pawła Zbroję na XLVIII Sesji Studenckich Kół Naukowych Pionu Hutniczego AGH 2011 w Sekcji Inżynieria Spajania, który został wyróżniony I nagrodą. Opiekun naukowy referatu - prof. dr hab. inż. Edmund Tasak.

Badania wykonano w ramach pracy statutowej nr 11.11.110.790 